\title{
14. SEISMIC STRATIGRAPHY AND RELATED LITHOFACIES OF THE BLAKE-BAHAMA BASIN
}

\author{
Robert E. Sheridan, Department of Geology, University of Delaware, Newark, Delaware, \\ Léo Pastouret,' Centre National Pour L'Exploitation Dés Oceans, Brest, France, \\ and \\ Georges Mosditchian, Institut Français du Pétrole, Rueil-Malmaison, France
}

\section{INTRODUCTION}

The seismic stratigraphy of the Blake-Bahama Basin is interesting because of the apparent acoustic blanking of the deeper reflectors. The blanking is caused by shallow high impedance layers, diffractions at shallow hyperbolic reflectors, and velocity inversions. Only recently have high-energy multichannel seismic techniques been employed in the basin to reveal the true configuration of the deeper reflectors and the extent of the blanking (Figure 1). In 1974 a cooperative U.S. Geological Survey-Institut Français du Pétrole cruise aboard R/V Florence collected three profiles, FC I, II, III, using a 24-fold Flexichoc system (Dillon et al., 1976). DSDP Site 391 was selected on the basis of these U.S.G.S.-I.F.P. seismic data. A survey aboard R/V Conrad was made in 1975, after Leg 44 drilling, to collect the 24-fold multichannel lines MC 1 and 2 . The survey extended the seismic coverage in the area and provided ties to Sites 390 and 391 (Windisch et al., 1976).

The institutional seismic reflection profiles, such as those made by Lamont-Doherty Geological Observatory using small volume airguns, failed to penetrate horizon A. Consequently, before the availability of these multichannel data, little was known about the deeper structure (Figure 2).

\section{MIOCENE REFLECTORS}

At least two widespread and prominent reflectors above horizon $A$ cross the Blake-Bahama Basin and outer ridges. One is a near-horizontal apparently well-stratified reflector which is probably an upper Miocene turbidite horizon. These turbidites appear to cover most of the present Blake-Bahama Abyssal Plain, whereas to the east they appear to lap against the relief of reflector $X$ (Sheridan et al., 1974). Reflector $X$ has considerable relief under the BlakeBahama outer ridges and forms the core of the ridge structure as it must have existed during the Miocene (Markl et al., 1970).

Piston coring studies along the base of the Blake Escarpment yielded the first suggestion that the BlakeBahama Abyssal Plain was underlain by Miocene turbidites (Figure 3) (Sheridan et al., 1974). Smallvolume airgun profiles made from $\mathrm{R} / \mathrm{V}$ Eastward

'Contribution number 538 of the Départment Scientifique, Centre Océanologique de Bretagne. traced the prominent reflector above horizon $A$ to a possible outcrop (Figure 4). Apparently, strong contour-currents flowing southward along the base of the escarpment had eroded and swept clean the younger sediments leaving the Miocene turbidites exposed. Three piston cores recovered as much as 5 meters of chalk, calcareous silt, and white calcarenite with, interestingly, an intraclast of olive-green claystone (Figure 5). The displaced shallow-water foraminifers and ostracodes in these Miocene calcarenites indicate that they were deposited as turbidites, probably from a southern Bahama Banks source (Sheridan et al., 1974). The piston cores recovered a facies identical to the Miocene intraclastic chalks drilled at Site 391. These cores, from a prominent seismic horizon traceable to Site 391 , indicate that the Miocene intraclastic chalks underlie a vast area of the Blake-Bahama Basin, and that the prominent horizontal reflector is everywhere Miocene intraclastic chalk. The extent of these Miocene turbidites and debris flows could effectively be determined by seismic mapping.

The recently available multichannel reflection data add considerable information about the Miocene reflector. Larger sound sources and 24 -fold stacking resulted in enhanced resolution of the shallower sedimentary reflectors and yielded sub-horizon $A$ data. The best results on the shallower layers has thus far been achieved with the IFP Flexichoc system (profile FC II, Figure 6).

The IFP FC II profile runs generally north to south through DSDP Site 391. We can identify, through correlation with the drilling data, three sedimentary reflectors at Site 391 above horizon $A$ (Figure 6). The shallowest reflector, termed $M$ for Miocene turbidite (Dillon et al., 1976), is extensive and near-horizontal throughout the basin. Reflector $M$ correlates at Site 391 with the top of lithologic unit $2 b$ (see Site 391 report, this volume) the shallower Miocene massive intraclastic chalk. Velocity calculations on the basis of drilling depth indicate that a compressional wave velocity of this unit is $2.58 \mathrm{~km} / \mathrm{sec}$.

A second reflector below $M$ is correlated with the top of lithofacies $2 \mathrm{~d}$, the deeper Miocene massive intraclastic chalk. Velocity calculations from drilling depths yield a velocity of $2.25 \mathrm{~km} / \mathrm{sec}$ for this acoustic unit.

Another Miocene reflector occurs below the second intraclastic chalk reflector. At Site 391 it only exists as a thin unit just above horizon $A$. This bed is so thin at Site 391 that it does not produce a prominent reflector, 


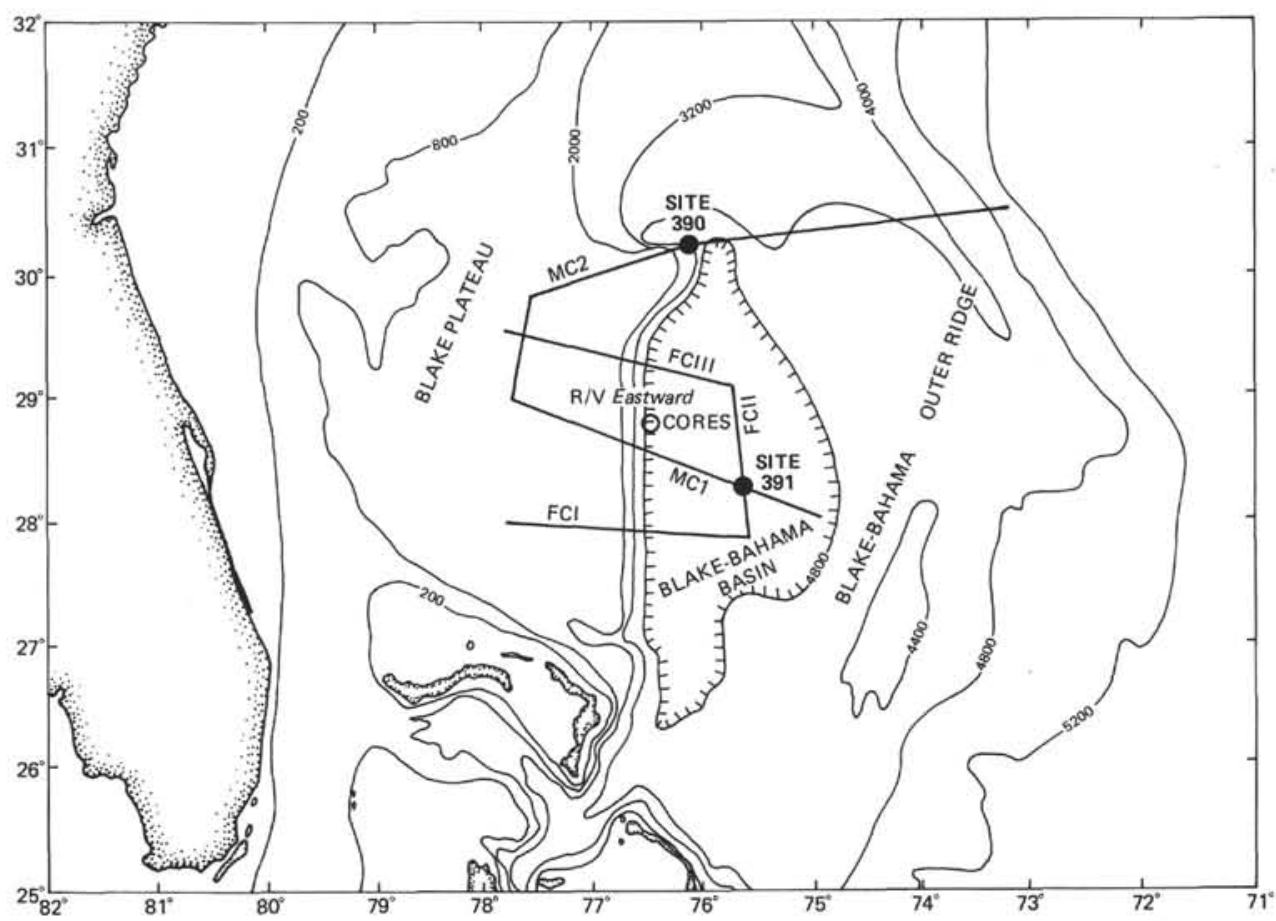

Figure 1. Location map showing the tracks of the available multichannel reflection profiles of $R / V$ Florence (FCI) and $R / V$ Conrad $(\mathrm{MCI})$ in the Blake-Bahama Basin, and across the Blake Escarpment. DSDP Sites 390 and 391, and the position of R/V Eastward piston cores at the base of the Blake Escarpment are also shown.

as it does to the south especially where the sediments between this reflector and horizon $A$ thicken markedly (Figure 6). We tentatively correlate this unit with the lower Miocene mudstone of lithologic unit 2e, in which the lithology contrasts markedly with the more massive intraclastic chalks of $2 \mathrm{~d}$ above (see Site 391 report, this volume).

Both reflectors between $M$ and $A$ are irregular with marked relief and erosional pinchouts and windows (Figure 6). The deeper of these two Miocene reflectors has a hyperbolic or rough surface as if it had originally been an erosional surface. Profile FC I which ties into profile FC II on its southern end shows that this deeper erosional reflector rises considerably until it pinches directly against reflector $M$ (Figure 7). This confirms the erosional nature of this now buried surface.

On profile FC I, the sediments below the hyperbolic erosional reflector and above horizon $A$ are characteristically unstratified and lack internal reflectors. Some internal hyperbolic reflectors in this unit might be caused by choatic slump structures. Lack of stratification and possible slumping suggest that these sediments could indeed be a thick unit of homogeneous lower Miocene mudstone drilled at Site 391 (lithologic unit 2e).

The relief seen on profile FC I indicates that during the early Miocene this mudstone was radiolarian-rich ooze indigenous to the Blake-Bahama Basin. It was later sculpted into ridge and swale topography by either strong bottom currents or by avalanches of Miocene debris flows which washed into the basin and deposited the overlying unit $2 \mathrm{~d}$. The indigenous muds have clearly been eroded as evidenced by the abundant clasts incorporated in the unit $2 \mathrm{~d}$ chalk.

We do not know whether the early Miocene (unit $2 \mathrm{e}$ drilled at Site 391) comprises all of the acoustic unit below the erosional reflector and above horizon $A$, or whether sediments of different lithologies and ages are included. The erosional nature of the reflecting horizon implies that it is diachronous, and this acoustic unit could quite possibly include sediments deposited after the formation of horizon $A$ until the Miocene erosion. The sediments, however, within the acoustic unit above horizon $A$ are extensively eroded and are nearly gone in some places. Moreover, no intraclasts of Oligocene, Eocene, Paleocene, and Upper Cretaceous basinal muds are found within this Miocene chalk unit, as would be expected if older beds were exposed.

We conclude that if Oligocene to Upper Cretaceous muds ever existed in the Blake-Bahama Basin they were eroded by strong currents which carried the mud far away and stripped the basin to form a nearly level horizon $A$. Later, after these strong currents subsided, the lower Miocene hemipelagic and radiolarian muds were deposited. Subsequently, the Miocene turbidites and debris flows scoured the lower Miocene muds as they spread across the basin and gouged out the older Miocene sediments. In asmuch as the Upper Cretaceous-Oligocene muds had already been stripped by the formation of horizon $A$, no muds of these ages were present to be incorporated in the intraclastic chalks.

There are no Cretaceous black shale clasts in the Miocene intraclastic chalk because after horizon $A$ was 

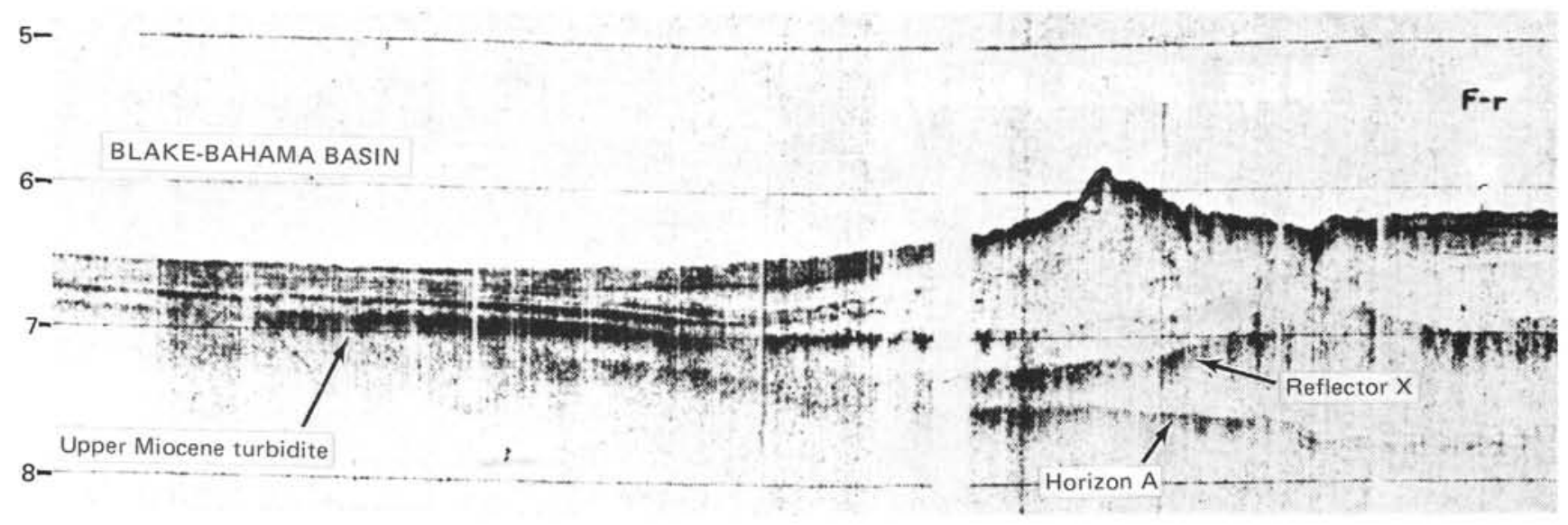

BLAKE

PLATEAU

(1)
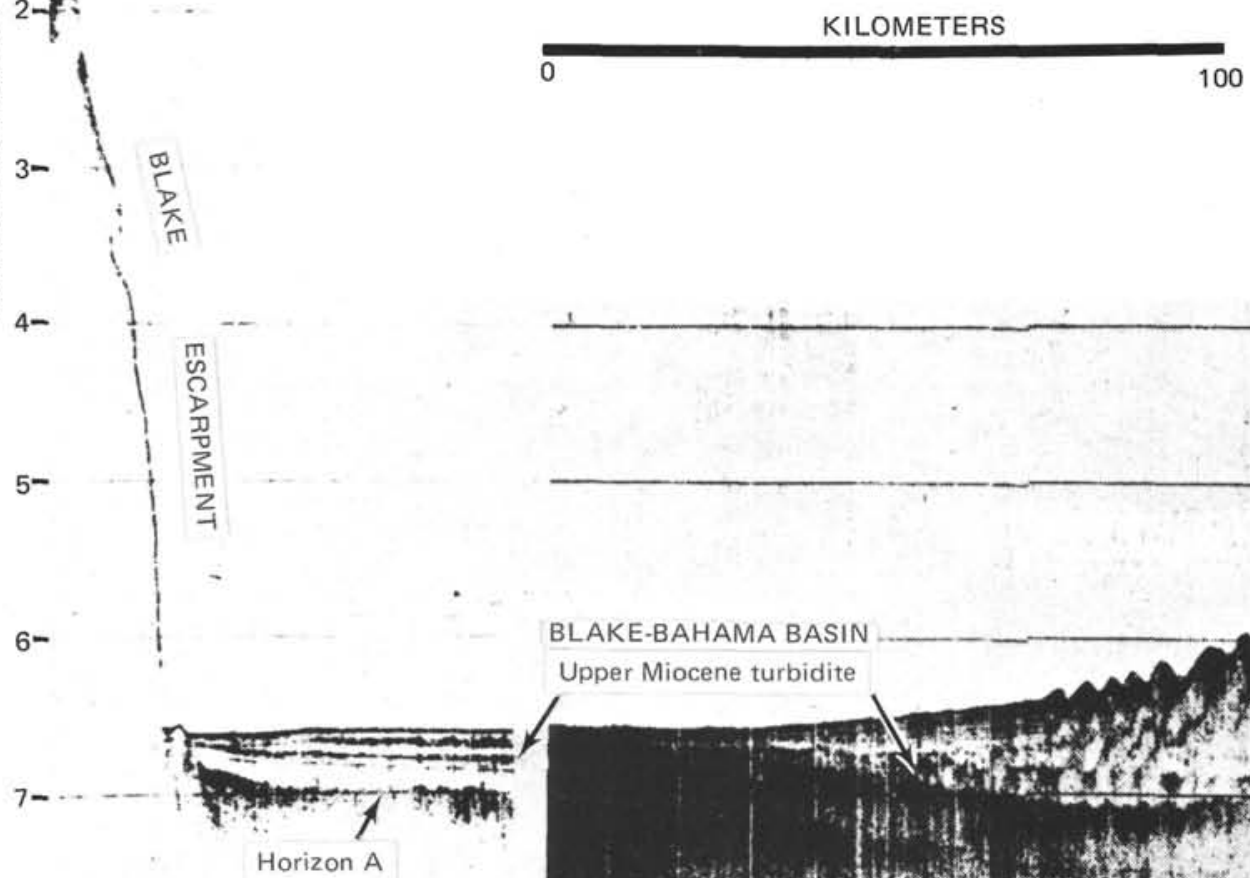

$8-$
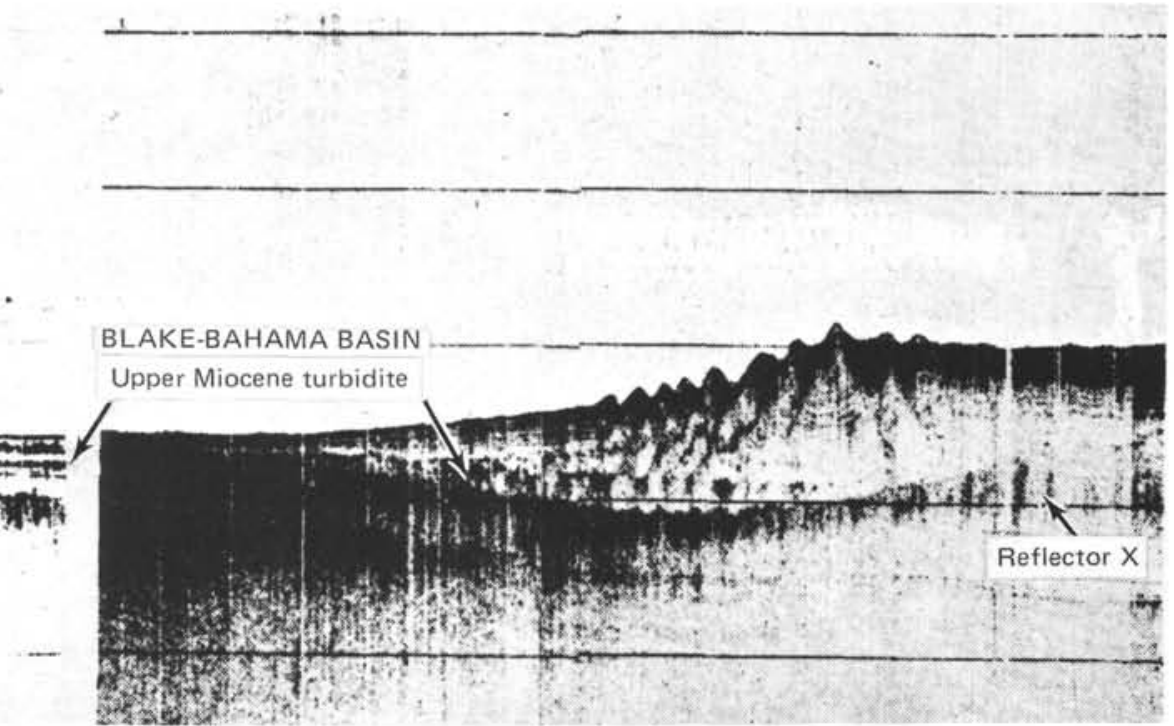

Figure 2. Lamont-Doherty single channel airgun profiles in the Blake-Bahama Basin (Markl et al., 1970). The upper Miocene turbidite horizon as interpreted by Sheridan et al. (1974) is noted, as are reflector $\mathrm{X}$ and horizon $\mathrm{A}$.

formed by erosion, the first Miocene deposits were hemipelagic and radiolarian-rich muds. Only this early Miocene basinal mud was eroded by the influx of turbidites and debris flows-not the underlying horizon A.

The hyperbolic nature of this reflector increases where the erosional reflector pinches with reflector $M$ on profile FC I (Figure 7). These hyperbolic diffractions are their "tails" are obscured on the older seismic records. Only since the processed profile (FC I) has been available has the origin of these hyperbolas been certain. The diffractions could have been caused by closely spaced faults, as shallow as the Miocene $M$ reflector, with about 20 -meter offsets and 200 -meter spacing. Dillon et al. (1976) suggest this in view of the possible basement faults and fracture zones that appear to offset magnetic anomalies in the area. Now, with the migrated FC I section, we know that the hyperbolic surface is caused by erosional roughness extending up to the $M$ reflector. Rills of 20 -meter relief and 200 meter spacing could produce the observed hyperbolic surface (Figure 8). Such steep-walled rills are formed by. strong erosive bottom currents flowing along the Bahama Outer Ridge on the eastern flank of the Blake- 


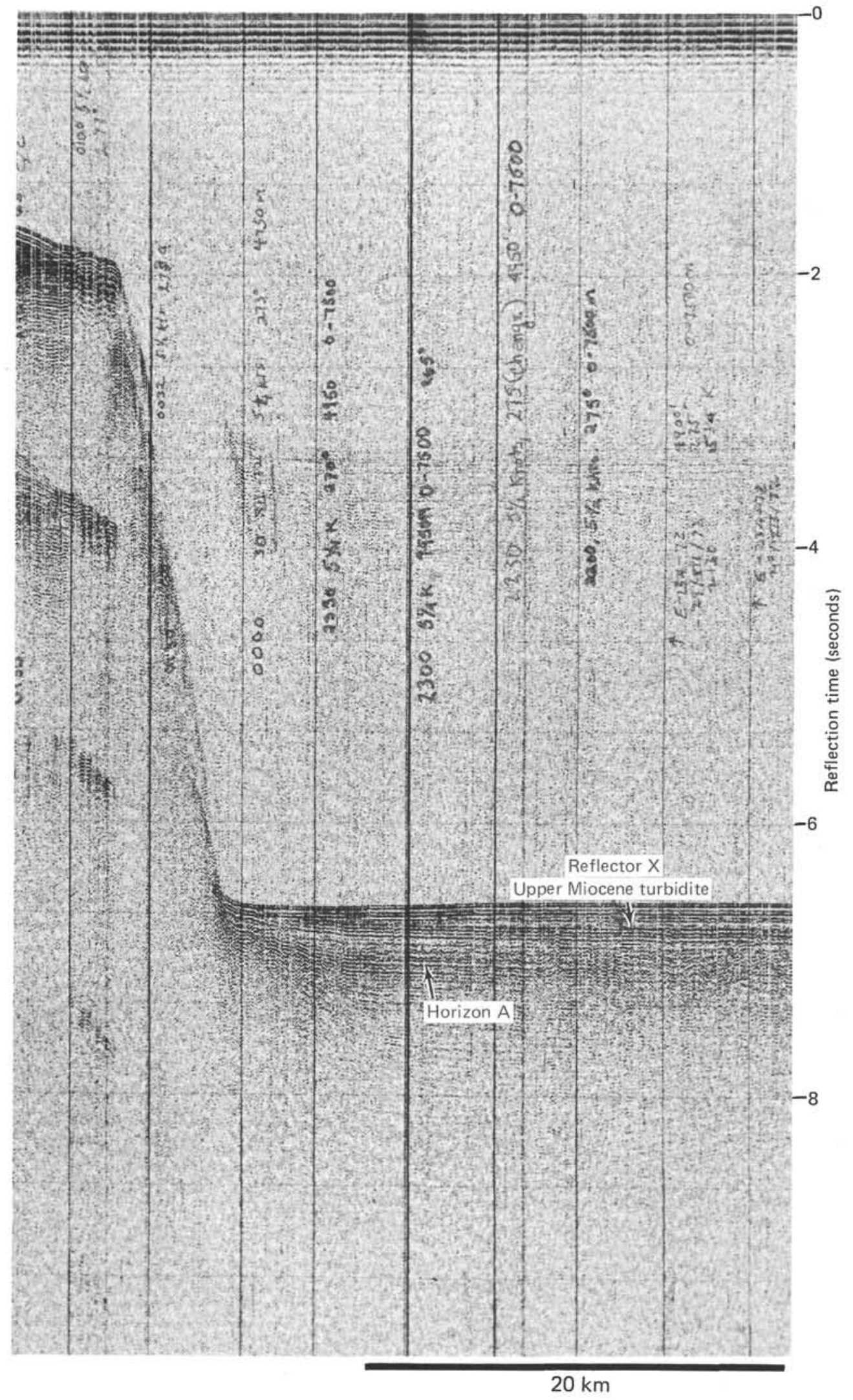

Figure 3. $R / V$ Eastward airgun profile tracing the upper Miocene reflector to a proven outcrop near the base of the Blake Escarpment (from Sheridan et al., 1974). 


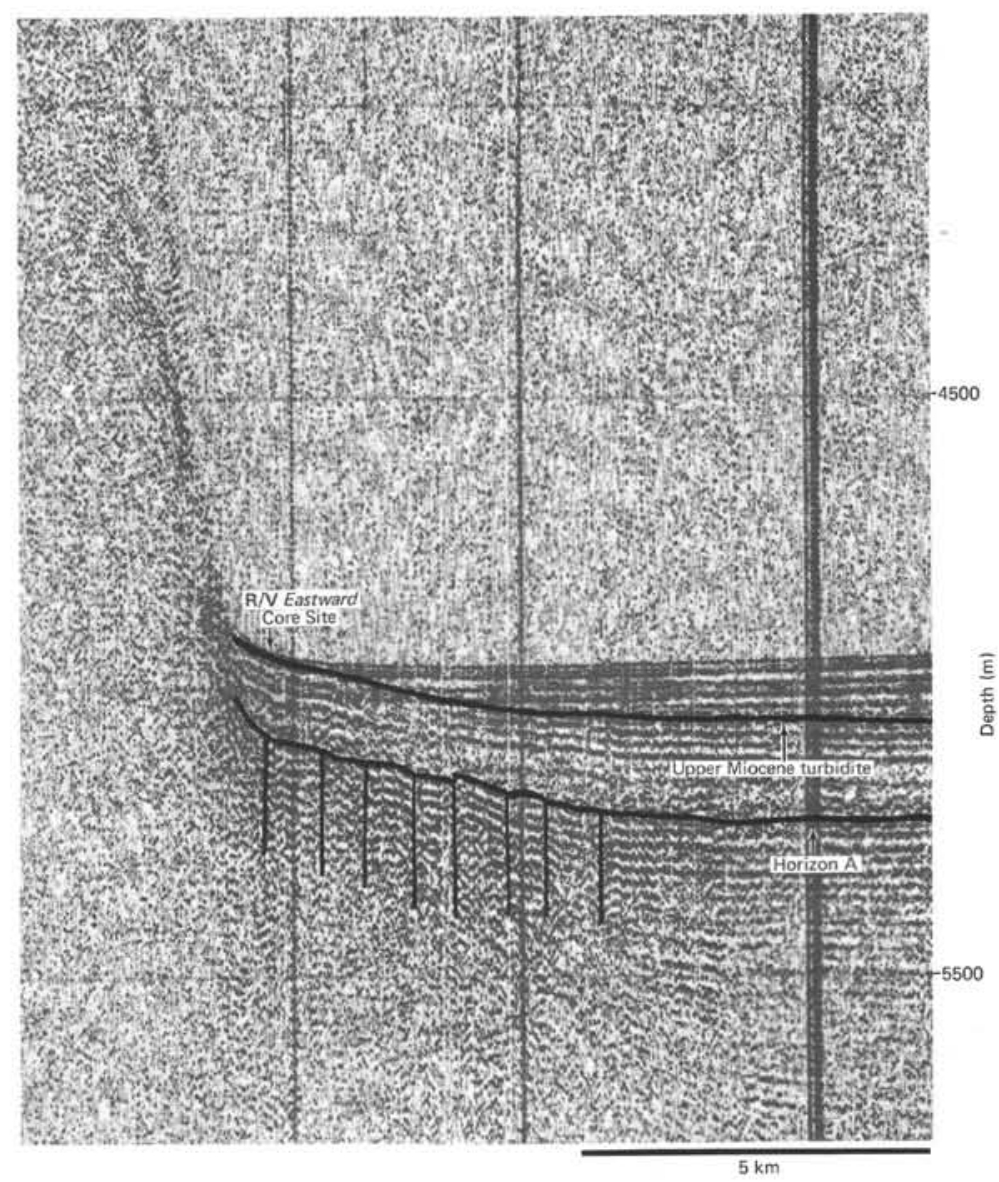

Figure 4. Enlargement of $R / V$ Eastward airgun profile showing outcrop of Miocene reflector at the core site (from Sheridan et al., 1970).

Bahama Basin (Flood and Hollister, 1974). Similar ridge-like structures existed in the early Miocene within the Blake-Bahama Basin as evidenced in profile FC I.

These same hyperbolic reflectors on profile MC I suggest that the Miocene ridge feature trends northsouth (Figure 9). The diffractions originate as shallow as reflector $M$ and are abundant about midway across the basin between the Blake Escarpment and DSDP Site 391 . If these are a continuation of the same roughsurfaced ridge as on FC I, then this feature is aligned north-south in the central part of the basin (Figure 10).

North of MC 1 this distinct hyperbolic zone is not evident on profile FC III (Figure 1), whereas reflector $M$ is distinct as a stratified flat-lying horizon. Somewhere between profiles FC III and MC 2, however, reflector $M$ disappears as does horizon $A$ (Figure 11). Reflector $X$ of Markl et al. (1970) and horizon $\beta$ which is pinched out against horizon $A$ on the eastern end of MC 2 are identifiable. Just south of the Blake Nose, reflector $M$ laps against the apparently older reflector $X$.

\section{VELOCITY ANALYSES}

Several Miocene acoustic units were cored at Site 391. The intraclastic chalks have a relatively high compressional seismic wave velocity of $2.58 \mathrm{~km} / \mathrm{sec}$ (acoustic unit II and $2.25 \mathrm{~km} / \mathrm{sec}$ (acoustic unit III) (Figure 12). These well-cemented rocks have a higher velocity than the underlying Cretaceous black shale which has a calculated velocity of $1.97 \mathrm{~km} / \mathrm{sec}$ (acoustic unit IV). The inversion is caused by less consolidation by compaction of the non-calcareous black shales and perhaps by contained gas (as noted in the cored samples) within these shales. Either factor could lower the shale's velocity.

If this inversion and relatively high velocities for the Miocene intraclastic chalks are characteristic of these lithofacies, then we could use closely spaced velocity analyses to map the units away from Site 391 . Velocity analyses were made at about every $5 \mathrm{~km}$ across the Blake-Bahama Basin (Figure 12) with the digital multichannel data of $\mathrm{R} / \mathrm{V}$ Conrad profile MC 1. The semblance technique of Taner and Koehler (1969) was applied to graphically plotted velocity spectra by use of the velocity analysis programs of Lamont-Doherty Geological Observatory (Figure 13). A marked change in slope of the picked RMS velocity curves on many spectra. This gives the calculated velocity inversion at horizon $A$ similar to that detected by the drilling data.

To further illustrate the lateral velocity variations away from Site 391 , the individual velocity scans at points $5-\mathrm{km}$ apart were averaged over $40 \mathrm{~km}$ stretches 


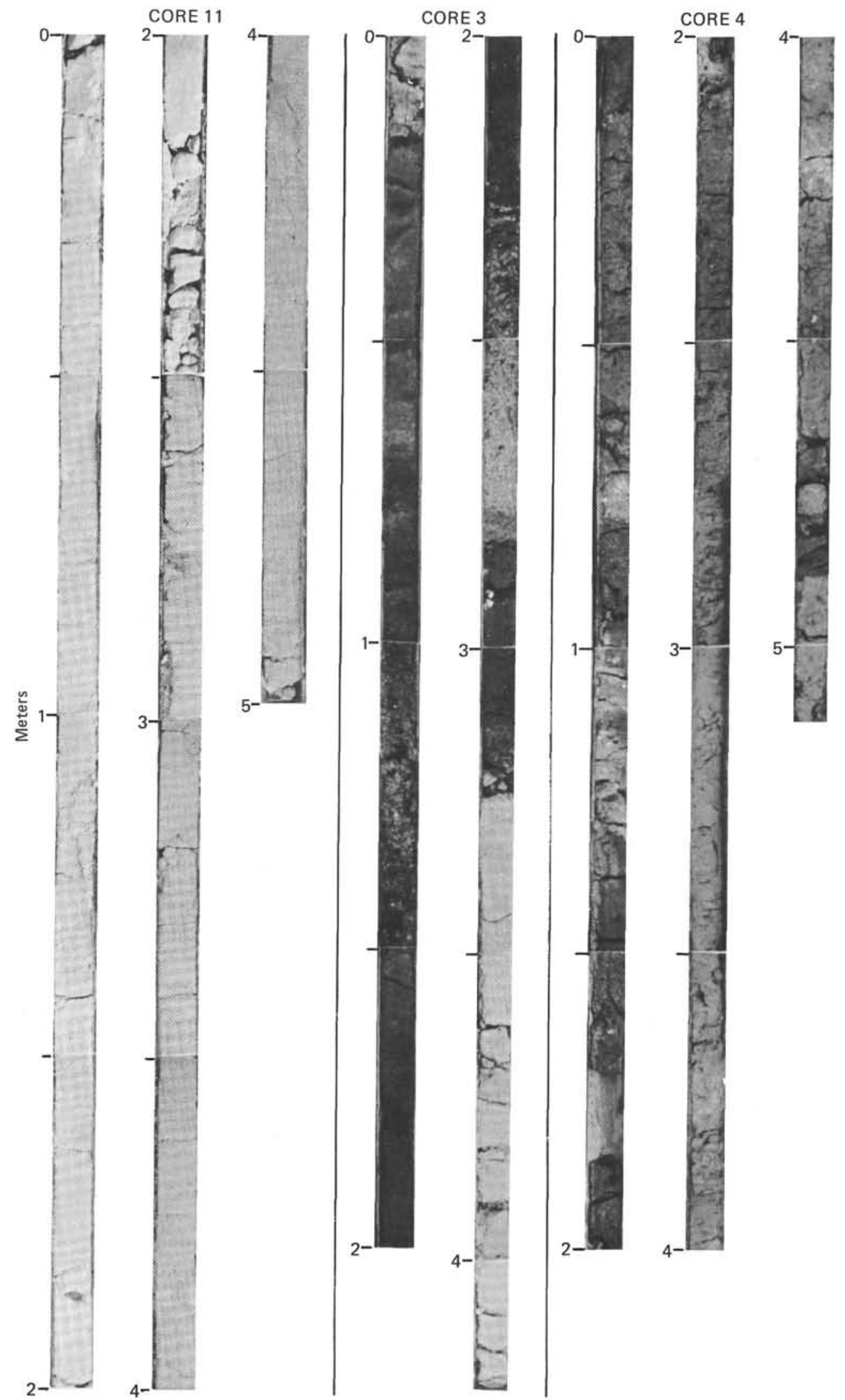

Figure 5. Photographs of $R / V$ Eastward piston cores 3, 4, and 11 showing the upper Miocene white calcarenite, silt, and chalks of turbiditic origin recovered at the outcrop of the prominent $\mathrm{M}$ reflector (Figure 4). Note the intraclast of green mud at 1.85 meters in Core 11; it is nearly identical to the clasts found in the Miocene chalks at Site 391 (from Sheridan et al., 1974). 


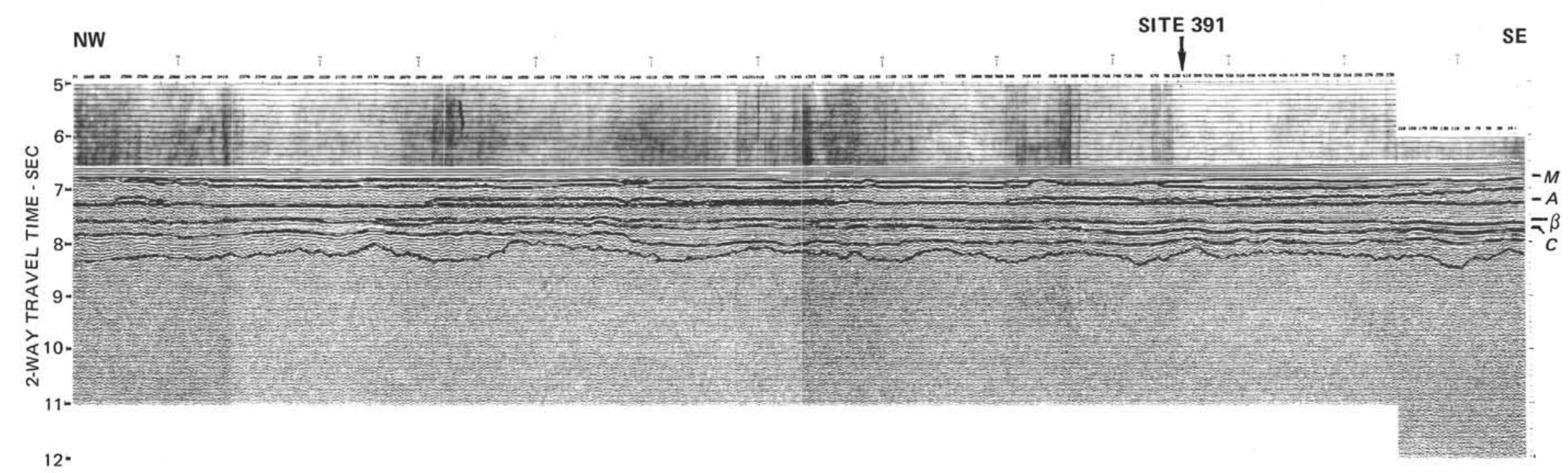

Figure 6. Original 24-fold multichannel seismic reflection profile FC II north-south through Site 391. Reflectors, M, A, $\beta$, and $\mathrm{C}$ are noted. 
$\ddot{i}$

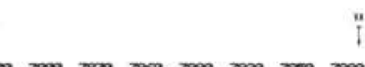

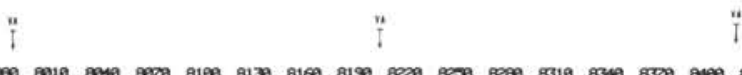

i

i

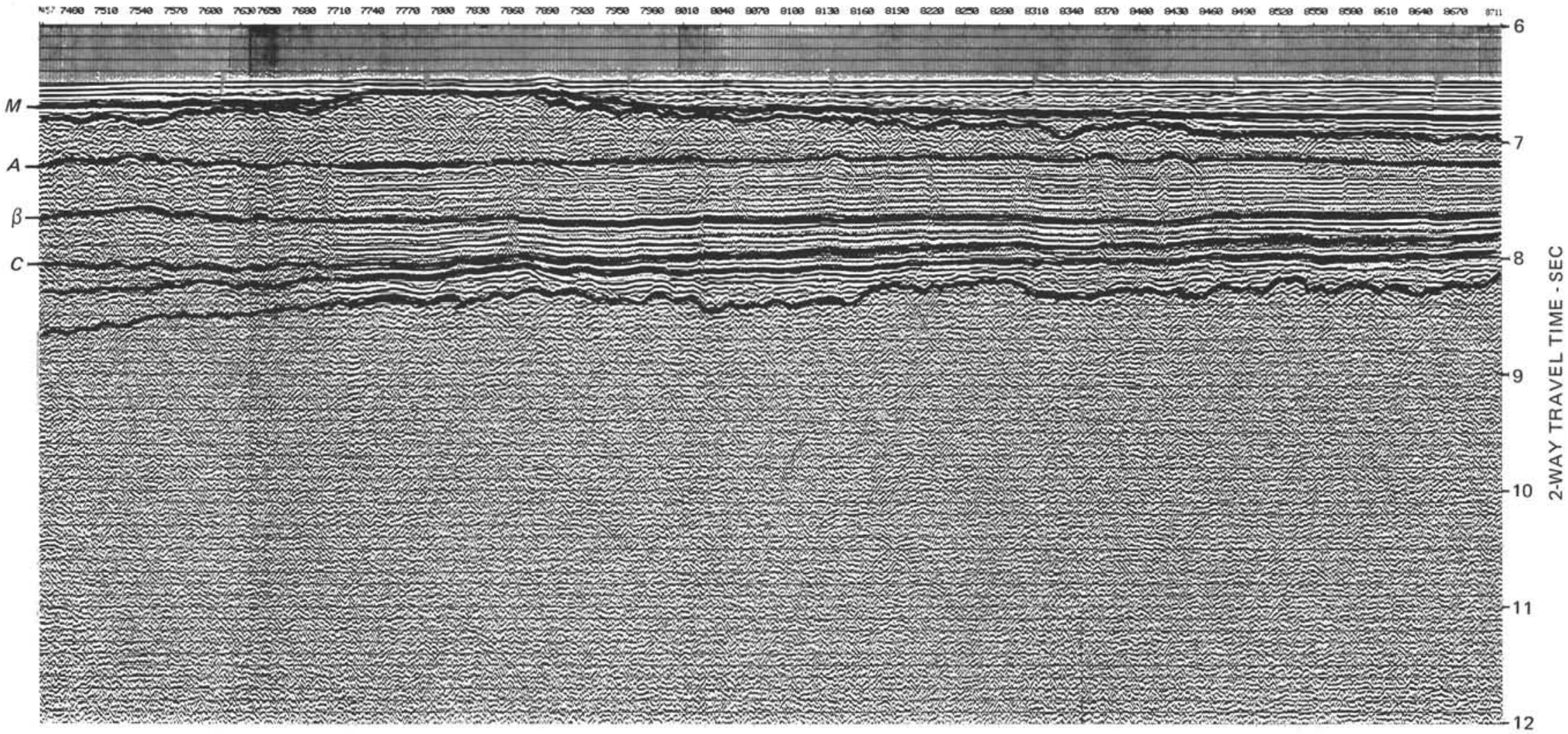

Figure 7. Original 24-fold multichannel seismic reflection profile FC I across the Blake-Bahama Basin. Reflectors $\mathrm{M}, \mathrm{A}, \beta$, and $\mathrm{C}$ are noted as correlated by tying to FC II and Site 391. 


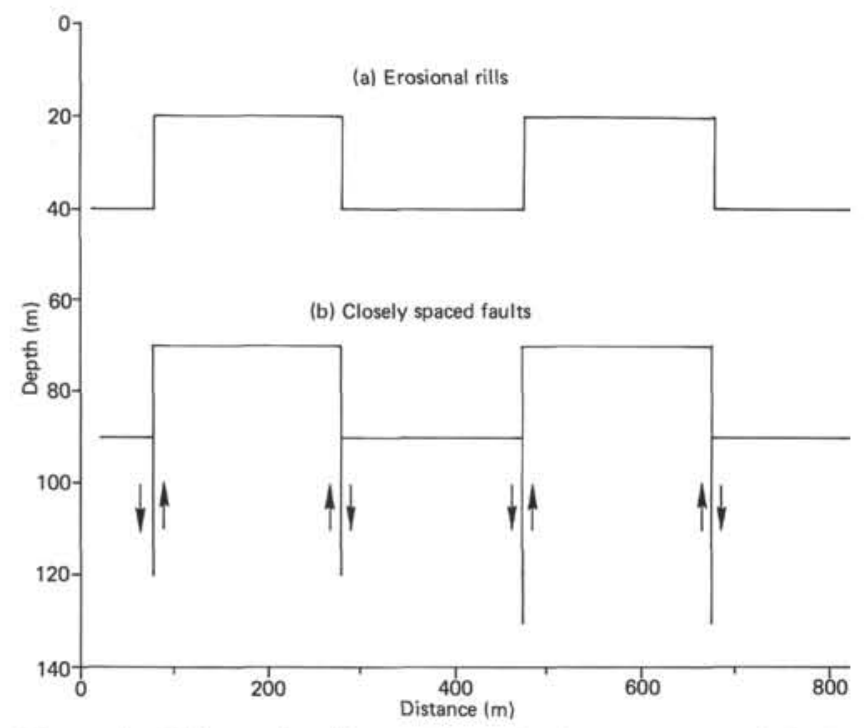

Figure 8. Schematic illustration of sharp cornered fault blocks with small 20-meter throw and 200-meter spacing which could generate the diffraction hyperbolic reflection seen on profile FCI. Alternatively, the sharp-walled rills of similar dimensions cutting into a mud substrate, as found by Flood and Hollister (1974) on the present Bahama Outer Ridge sea floor, could also cause the hyperbolic reflectors.

in three distinct parts of profile MC 1: one west of the Miocene hyperbolic reflectors, one including the hyperbolic reflectors, and one east of the hyperbolic reflectors (Figure 12). The averaging smoothed out the few possible spurious velocity data for the various acoustic units and yielded more consistent values than did any one scan.

These results showed that the velocity inversion persists well westward in the Blake-Bahama Basin and occurs consistently below horizon $A$. Also, the relatively high seismic velocities for the Miocene intraclastic chalks is well documented near Site 391, where averaged values of $2.92 \mathrm{~km} / \mathrm{sec}$ and $3.04 \mathrm{~km} / \mathrm{sec}$ were calculated.

In the area of the hyperbolic reflectors, the Miocene units have consistently lower velocities of $2.63 \mathrm{~km} / \mathrm{sec}$, and the two units recognized at Site 391 are no longer distinguishable. This is consistent with the interpretation of profile FC I (Figure 7) where the lower Miocene mudstone (unit 2e) thickens to pinch against the $M$ reflector of the shallower intraclastic chalk (unit $2 \mathrm{~b}$ ). The mudstone has a lower velocity than the overlying chalks, as demonstrated by the drilling at Site 391. Thus the hyperbolic reflectors on MC 1 also appear to be caused by a Miocene mud ridge with clastic chalk debris flows lapping on from the east. Details of this relationship are lost in the diffractions on MC 1 (Figure 9).

West of the hyperbolic zone the interval velocities for the Miocene sediments (between $M$ and $A$ ) continue to decrease to $2.21 \mathrm{~km} / \mathrm{sec}$ and $2.48 \mathrm{~km} / \mathrm{sec}$, which suggests that there is less chalk and more radiolarianrich mudstone in this area. Below horizon $A$, the black shale has a higher velocity $(2.58 \mathrm{~km} / \mathrm{sec})$ and the inversion disappears.
Other velocity-analysis data are available from IFP (Figures 14, 15, 16). Velocity spectra calculations of interval velocities were made at $10-\mathrm{km}$ intervals along profiles FC I, II, III. These measurements give consistent values of about $2.20 \mathrm{~km} / \mathrm{sec}$ for the shallowest layer, $2.50 \mathrm{~km} / \mathrm{sec}$ for the Miocene intraclastic chalk, and about $2.10 \mathrm{~km} / \mathrm{sec}$ for the Cretaceous black shale. These data confirm that the velocity inversion at horizon $A$ is widespread and the velocity of the limestone below horizon $\beta$ is consistently about 3.50 $\mathrm{km} / \mathrm{sec}$. The IFP measurements did not detect any marked lateral variations or any distinct separate velocity units within the Miocene sediments or between horizon $\beta$ and basement.

\section{HORIZON $A$}

Horizon $A$ forms a well-defined marker, except in the hyperbolic zone where it is obscured by the tails of the diffractions from the rough reflector in the overlying Miocene (Figures 6, 7, 9, 10). It is relatively planar or smooth where it is clearly visible. Between horizon $A$ and horizon $\beta$ the acoustic unit IV has consistent seismic velocities of between $2.53 \mathrm{~km} / \mathrm{sec}$ and 2.83 $\mathrm{km} / \mathrm{sec}$ on profile MC 1 (Figure 12), and consistent velocities of $2.10 \mathrm{~km} / \mathrm{sec}$ on the IFP profiles. This unit is characteristically homogeneous and transparent.

As noted above, horizon $A$ pinches out against horizon $\beta$ on the east end of profile MC 2, so that $\beta$ is directly in contact with possible Tertiary sediments below reflector $X$ on the west end of the profile (Figure 11). Apparently erosive bottom currents have swept along the margin of the Blake-Bahama Basin to completely remove the Cretaceous black shales in the area of MC 2. At Site 391, at least 800 meters of sediment had previously buried the black shale, only to have been eroded before deposition of the overlying Miocene sediments (Dow, this volume). The erosion was widespread throughout the basin and was most severe near the margin. During this erosive phase, sometime after the Albian but before the early Miocene, the deeper horizon $\beta$ was exposed along the base of the Blake Escarpment, under what is now the Blake Outer Ridge. These outcrops were much like that of horizon $\beta$ which exist today off San Salvador, where it is not buried by the Miocene mud and intraclastic chalk. Perhaps the horizon $\beta$ outcrop off San Salvador has been exposed on the sea floor since even before Miocene time.

\section{HORIZON $\beta$}

Although a weak reflector throughout the BlakeBahama Basin, horizon $\beta$ is discernible as a distinctly stratified, reverberatory reflector below the transparent acoustic unit V (Figures 6, 7, 9, 10, 11, 12). In some areas it is stronger than in other places and can be traced successfully on all the profiles. In one area on profile FC II (Figure 6) it apparently pinches out against the next deeper reflector, $C$ (see below for definition), and therefore some erosion could be associated with this horizon.

Seismic compressional wave velocities calculated on the basis of depths of sediments (by drilling at Site 391) were $3.65 \mathrm{~km} / \mathrm{sec}$ for the Neocomian-Tithonian limestone between horizon $\beta$ and reflector $C$. This 


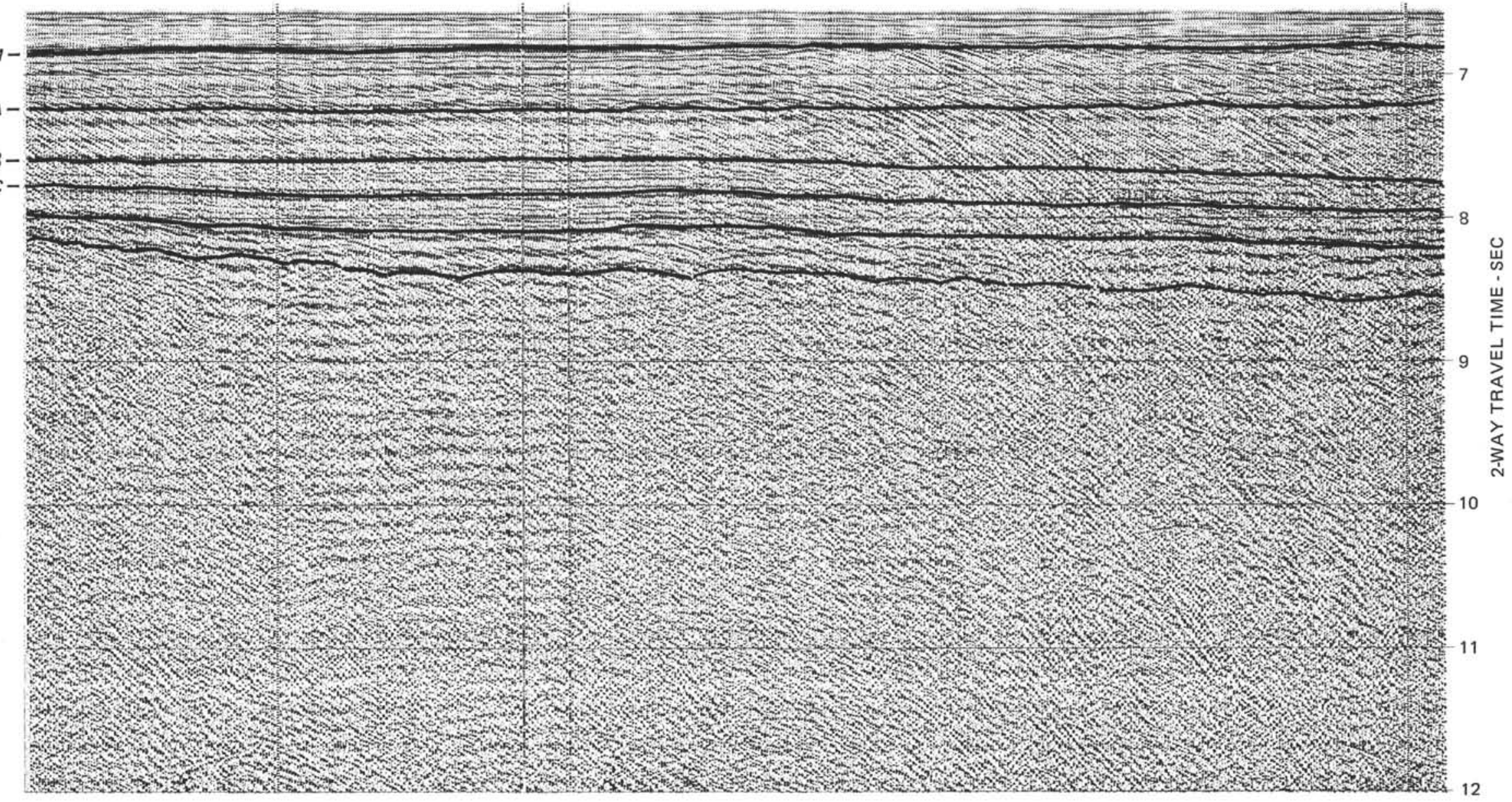

Figure 9. Original 24-fold multichannel reflection profile MC 1 across the Blake-Bahama Basin west of Site 391. Reflectors M, A, $\beta$, and C are noted on the basis of their correlation and tie with Site 391. 


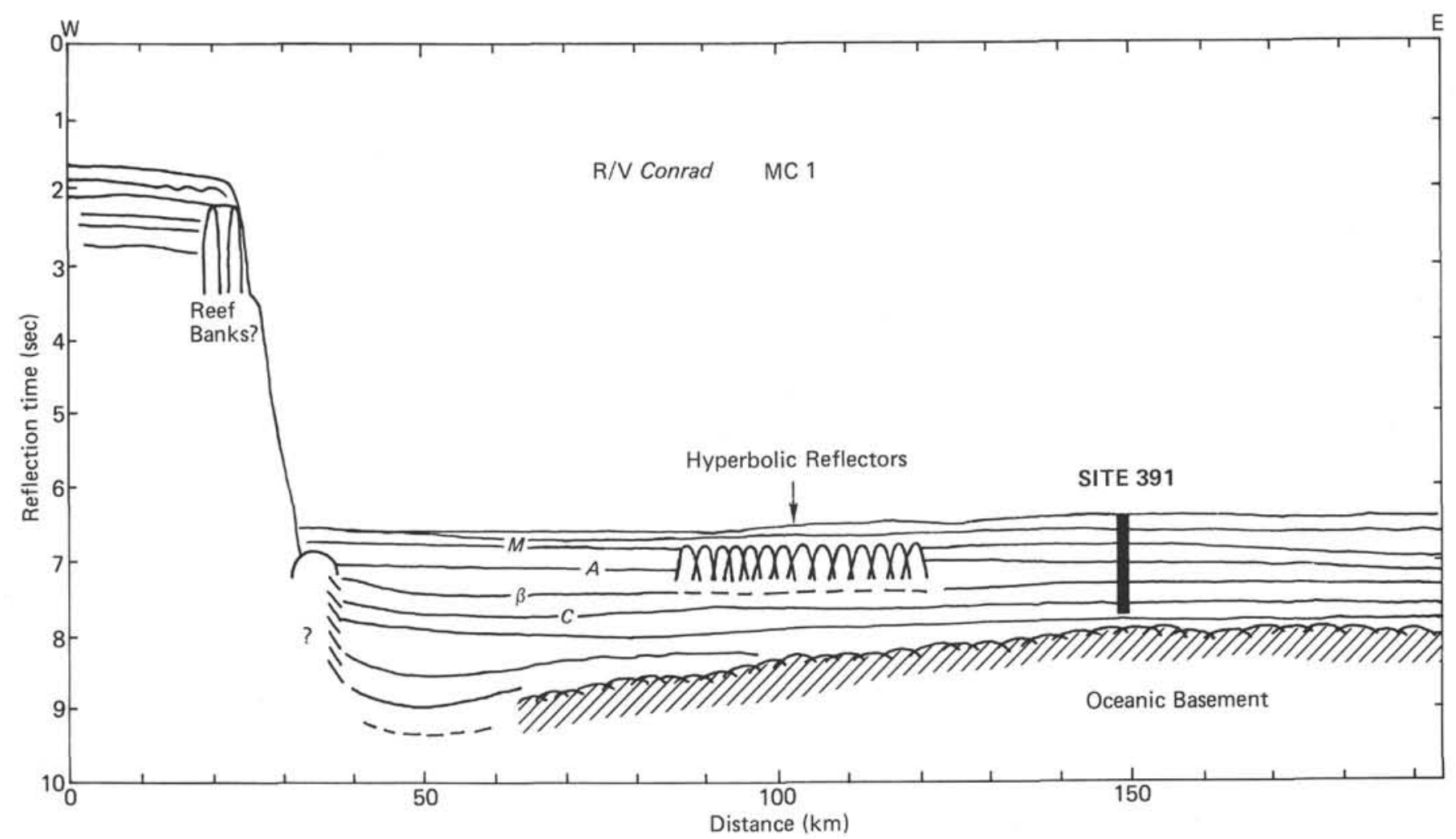

Figure 10. Line tracing of $R / V$ Conrad reflection profile $M C 1$ west to east across Site 391. Reflectors $\mathrm{M}, \mathrm{A}, \beta$, and $\mathrm{C}$ are noted as are the hyperbolic diffractions in the Blake-Bahama Basin.

velocity is consistent with the interval velocities determined from the velocity scans on the Conrad line MC 1. They are $3.23 \mathrm{~km} / \mathrm{sec}$ to $3.48 \mathrm{~km} / \mathrm{sec}$ determined on the average for acoustic unit V (Figure 12). The IFP data also supports these values with velocities of 3.50 $\mathrm{km} / \mathrm{sec}$ being consistently found on these profiles FC I, II, and III (Figures 14, 15, 16). Similar values were reported earlier on the basis of two ship refraction profiles (Sheridan et al., 1966), and correlated with the horizon $\beta$ limestones identified as a $3.6-\mathrm{km} / \mathrm{sec}$ velocity layer (Sheridan, 1969). These velocity values are apparently consistent for the Neocomian-Tithonian limestone throughout the basin.

Note that as $\beta$ is traced westward it terminates abruptly at the base of the Blake Escarpment against an opaque hyperbolic reflecting structure (Figures 10 and 11). Here, horizon $\beta$ and the reflectors below turn up against what appears to be an opaque western wall of a faulted half graben; the west wall was thrown up. Sediments in this half-graben trough are as deep as 9.5 sec on profile MC 1 (Figure 10), and $10.5 \mathrm{sec}$ on MC 2, where the trough is considerably narrower and the walls considerably steeper (Figure 11).

If the upturned reflectors on the boundary fault wall of the half graben are the result of differential motion and drag, then the fault motion apparently occurred through Jurassic to Neocomian or Barremian time and caused the deformation of horizon $\beta$. However, after Neocomian time, the sediments of horizon $A$ were deposited across the half graben without deformation and tilting which suggests an end to the graben development.

\section{REFLECTOR $C$}

A prominent, well stratified, reverbatory reflector below horizon $\beta$ appears on all the profiles MC 1 and 2, and FC I, II, and III (Figures 6, 7, 9, 10, 11). This reflector corresponds, at Site 391, to the top of the red argillaceous Tithonian limestone. It forms the interface between acoustic units V and VI (Figure 12). Here we call it reflector $C$, following the terminology of Lancelot et al. (1975) who detected the prominent reflector at the same stratigraphic position in the Eastern Atlantic. This reflector is widespread and it appears to be stronger than $\beta$ in the Blake-Bahama Basin. It extends laterally under the western North Atlantic continental rise (Figure 17). Because of its prominence, extent, and existing correlation at Site 391, it is named reflector $C$.

Velocities below reflector $C$ are distinctly higher than those of the overlying limestones; the average values measured for unit VI on profile MC 1 are 3.40 to 4.28 $\mathrm{km} / \mathrm{sec}$ (Figure 12). The resulting depth section shows that reflector $C$ dips to the west and that the overlying limestones thicken significantly. This dip is caused by the tilt to the west with active deformation in the half graben during Neocomian-Tithonian time.

Lateral variations of the averaged velocity values for acoustic unit VI below reflector $C$ are seen on MC 1 (Figure 12). Near Site 391, where this acoustic unit is argillaceous limestone, higher velocities $(4.28 \mathrm{~km} / \mathrm{sec})$ are measured. Westward, toward the graben, the velocities drop to $3.40 \mathrm{~km} / \mathrm{sec}$ which suggest that the sediments are more clastic or argillaceous. Perhaps 


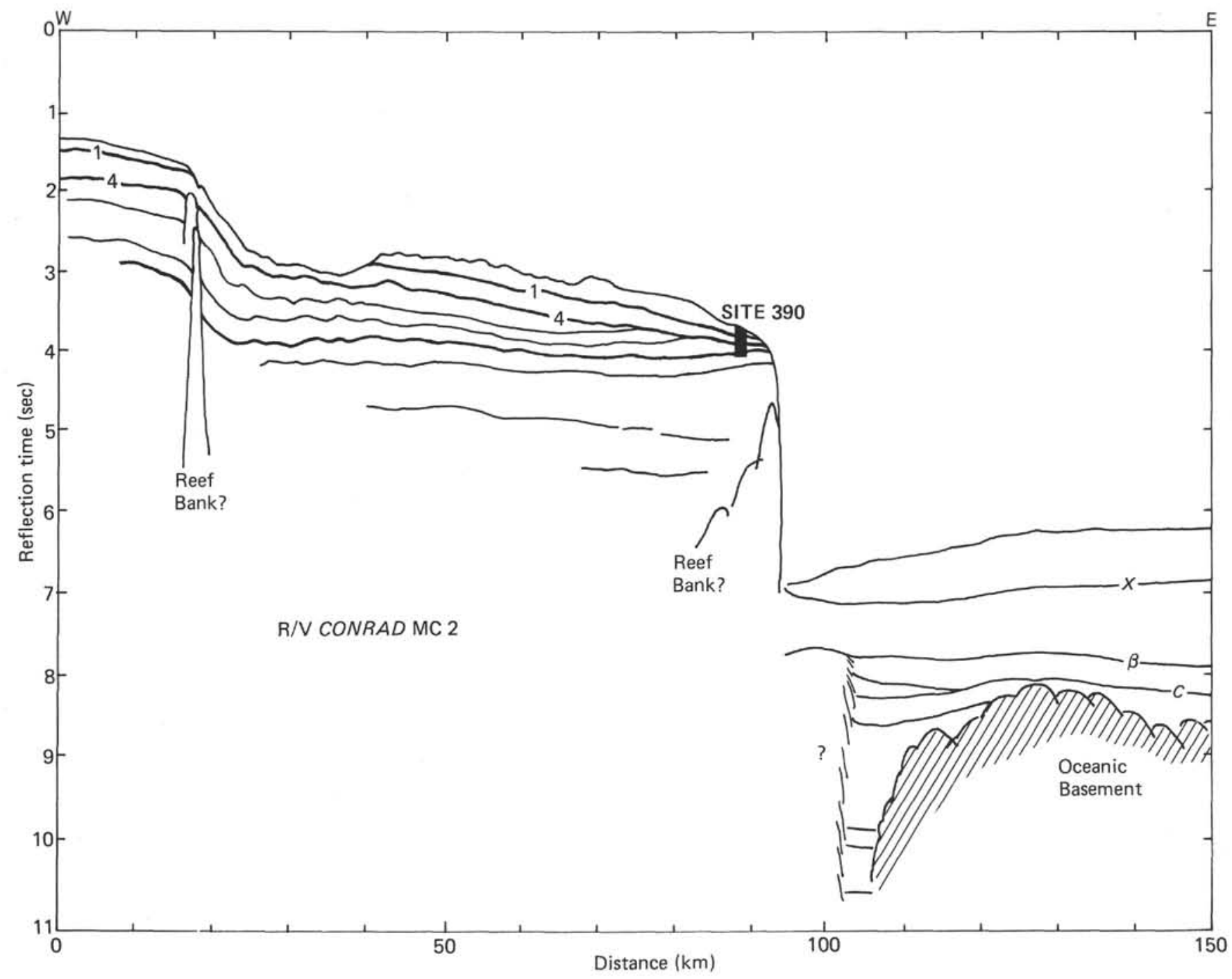

Figure 11. Line tracing of R/V Conrad reflection profile MC 2 across the Blake Nose at Site 390. Reflectors 1 and 4 (after Ewing et al., 1966) and X (Markl et al., 1970), are noted. The hyperbolic opaque reflections are probably caused by highly cemented high-velocity reef-bank or reef-complex limestone.

clastics were trapped in the graben and could not dilute the carbonates of unit VI deposited farther east.

\section{PRE-REFLECTOR $C$}

A strong well-stratified reverberatory reflector occurs below reflector $C$. It can be traced on all the available multichannel profiles (Figures 6, 7, 9, 10, 11). Unfortunately, it was not sampled at Site 391 so we do not know its lithofacies or age, although it appears to be older than any sediment yet drilled in the oceans. Because it is not distinguishable as a separate acoustic unit by the semblance technique (Figure 12), we included it with velocities of 3.40 to $4.28 \mathrm{~km} / \mathrm{sec}$ of the lower part of acoustic unit VI.

In the half-graben trough at the base of the Blake Escarpment there are at least two, and possibly three reflectors below this other pre- $C$ horizon (Figures 10 and 11). These reflectors are possibly Middle to Lower Jurassic sediment which fill the fault-bounded trough formed during the earliest opening of the North Atlantic. The averaged interval velocities for these sediments are between 3.55 and $3.95 \mathrm{~km} / \mathrm{sec}$ (Figure 12), which, because of the relatively low velocity in such deeply buried sediments, suggest that they are clastic.

\section{BASEMENT REFLECTOR}

The oceanic basement has a characteristic hyperbolic appearance with opaque internal structure on all the available profiles (Figures 6, 7, 9, 10, 11). Semblance technique velocity scans yielded averaged velocities of 5.14 to $5.46 \mathrm{~km} / \mathrm{sec}$ for the top of this acoustic layer. The next deeper reflector, however, is so poorly defined that velocity values are not as reliable as for the sediments above.

\section{BLAKE PLATEAU REFLECTORS}

The reflectors sampled and identified at the Blake Nose (Site 390, Figure 11), have now been tied westward to the shallow Blake Plateau by profile MC 2 .

The basal Eocene chert layer in the nannofossil ooze which causes a major reflector correlates seismically with reflector $I$ on the Blake Plateau, as identified by 


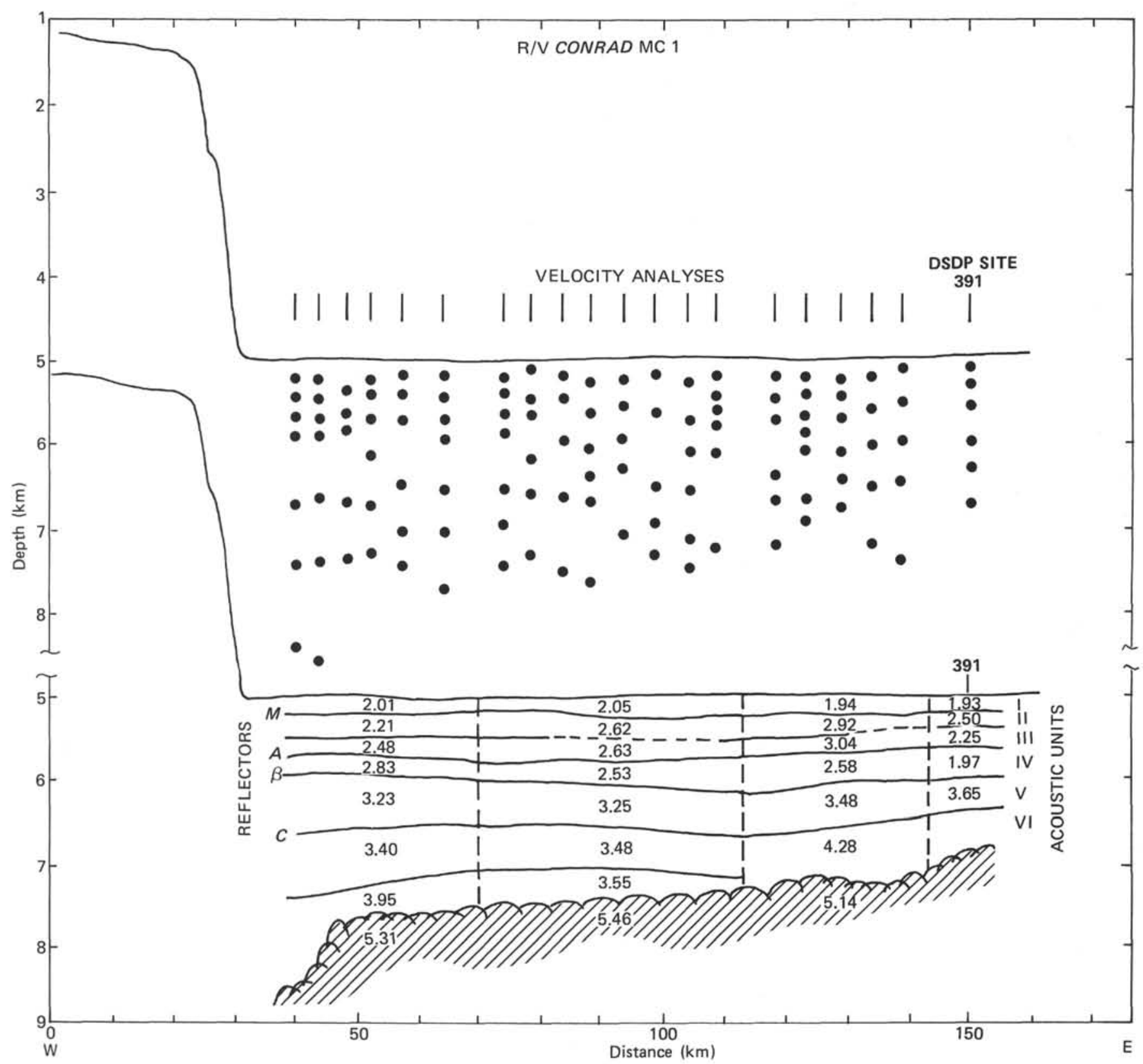

Figure 12. Location of RMS velocity picks for interval velocity calculations using the semblance technique of Taner and Koehler (1969) with averaged interval velocities for the various acoustic units along profile MC 1. Site 391 is shown with the interval velocities calculated on the basis of drilling depth.

Ewing et al. (1966). On the plateau, reflector $l$ is also a basal Eocene cherty limestone. Reflector 4, as identified on the Blake Plateau by Ewing et al. (1966), was correlated with the reflector at the Campanian/Albian unconformity on the Blake Nose. Thus, reflector 4 has Campanian sediments just above it on the plateau, but other Cretaceous sediments intervene between the Albian sediments and reflector 4 west of the unconformity at Site 390 . The sediments below reflector 4 are probably younger than Albian there.

The strong reflector cored at the bottom of the hole at Site 390 , corresponding to shallow water Barremian or older limestone, can be traced westward to the Blake Plateau where it seismically correlates with a prominent reflector at 2.5 to $3.0 \mathrm{sec}$ depth. The relief on this reflector at the junction of the Blake Plateau and Blake Nose appears to be merely a velocity effect. Corrections for interval velocities indicate that this horizon dips gently westward without real relief, and passes as a planar surface beneath the junction between the Blake Plateau and Blake Nose. Possible reef banks or cemented rim-complexes cause higher interval velocities under the plateau which cause the apparent relief on the time section (Figure 11).

\section{REFERENCES}

Dillon, W.P., Sheridan, R.E., and Fail, J.P., 1976. Structure of the Western Blake-Bahama Basin as shown by 24channel CDP profiling: Geology, v. 4, p. 459-462. 


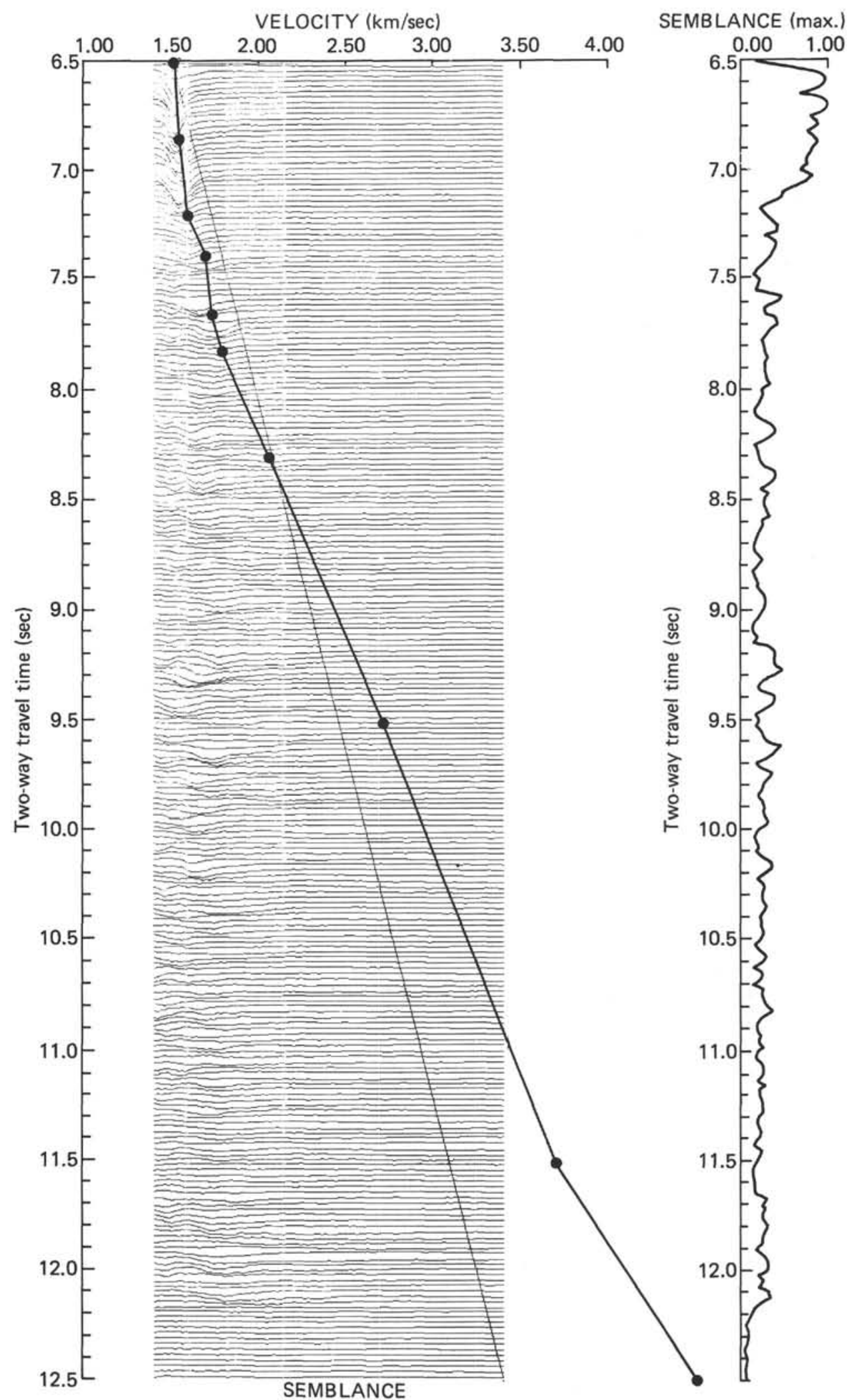

Figure 13. Original printout of graphic displacement of semblance velocity spectra used in the Taner and Koehler (1969) velocity analyses of profile MC 1. The picks of RMS velocity are shown. Note the change in slope of the RMS curve for the inversion below horizon A. $(7.4 \mathrm{sec})$ 


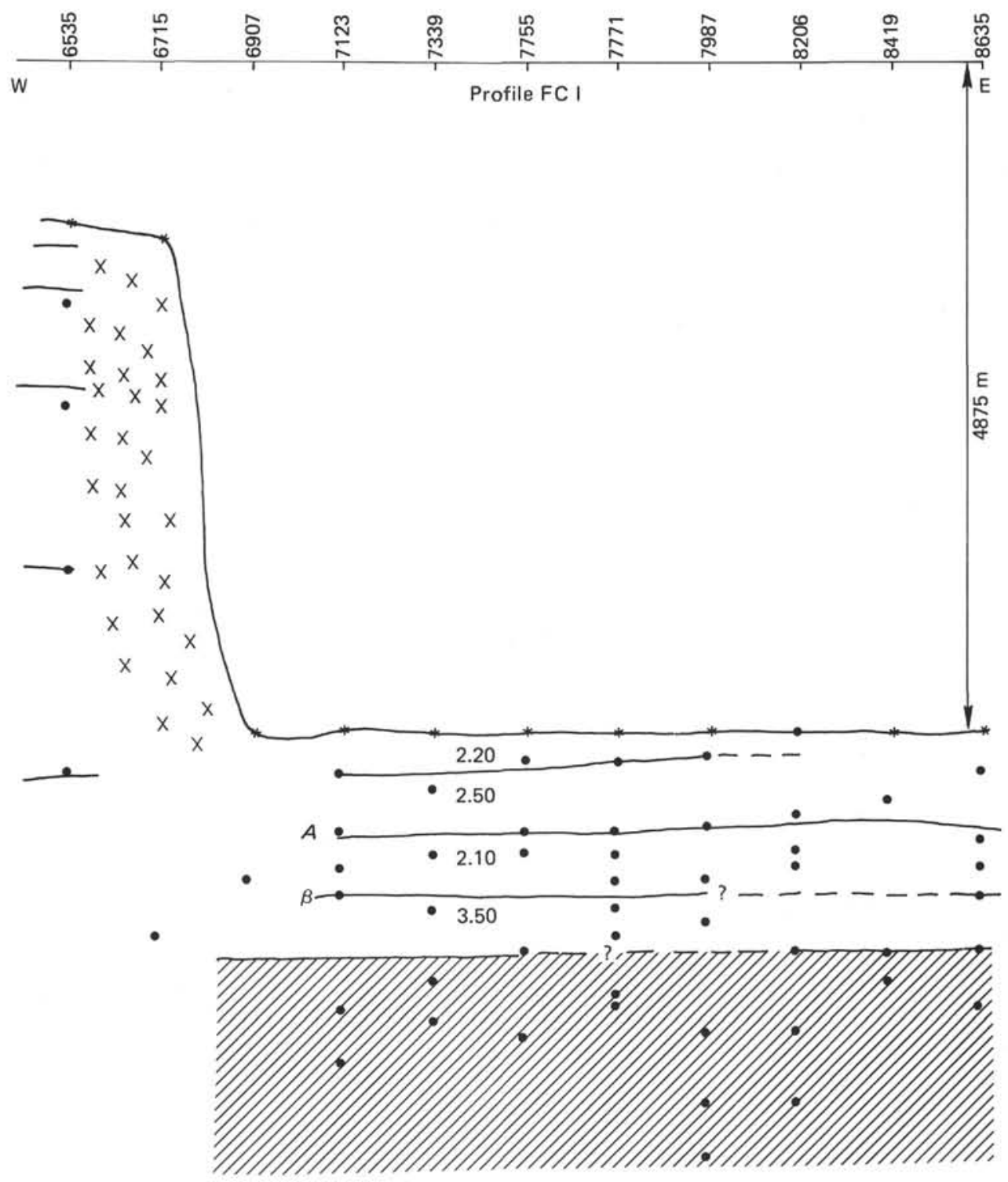

Figure 14. Location of RMS velocity picks for interval velocity calculations along profile FC I. Horizons A and $\beta$ and the interval velocities of the consistent acoustic units are also noted.

Ewing, J.I., Ewing, M., and Leyden, R., 1966. Seismic profiler survey of Blake Plateau: Am. Assoc. Petrol. Geol. Bull., v. 50 , p. $1948-1971$.

Flood, R.D. and Hollister, C.D., 1972. Current-controlled topography on the continental margin off the eastern United States. In Burk, C.A. and Drake, C.D. (Eds.), Geology of continental margins: New York (SpringerVerlag), p. 197-205.

Lancelot, Y., Seibold, E., Cepek, P., Dean, W.E., Eremeev, V., Gardner, J.V., Jansa, L.F., Johnson, D., Krasheninnikov, V., Pflaumann, U., Rankin, J.G., and Traband, P., 1975. The eastern North Atlantic: Geotimes, v. 20 , no. 7 , p. $18-21$.

Markl, R.G., Bryan, G.M., and Ewing, J.I., 1970. Structure of the Blake-Bahama Outer Ridge: J. Geophys. Res., v. 75, p. $4539-4555$.
Sheridan, R.E., 1969. Subsidence of continental margins: Tectonophysics, v. 7, p. 219-229.

Sheridan, R.E., Drake, C.L., Nafe, J.E., and Hennion, J.E., 1966. Seismic refraction study of the continental margin east of Florida: Am. Assoc. Petrol. Geol. Bull., v. 50, p. 1972-1991.

Sheridan, R.E., Golovchenko, X., and Ewing, J.I., 1974. Late Miocene turbidite horizon from the Blake-Bahama Basin: Am. Assoc. Petrol. Geol. Bull., v. 58, p. 1797-1805.

Taner, M.T. and Koehler, F., 1969. Velocity spectra digital computer derivation and applications of velocity functions: Geophysics, v. 34, p. 859-881.

Windisch, C.C., Sheridan, R.E., and Ewing, J.I., 1976. Multichannel seismic study of the Blake-Bahama Basin (obs): EOS Trans. Am. Geophys. Union, v. 57, p. 264. 


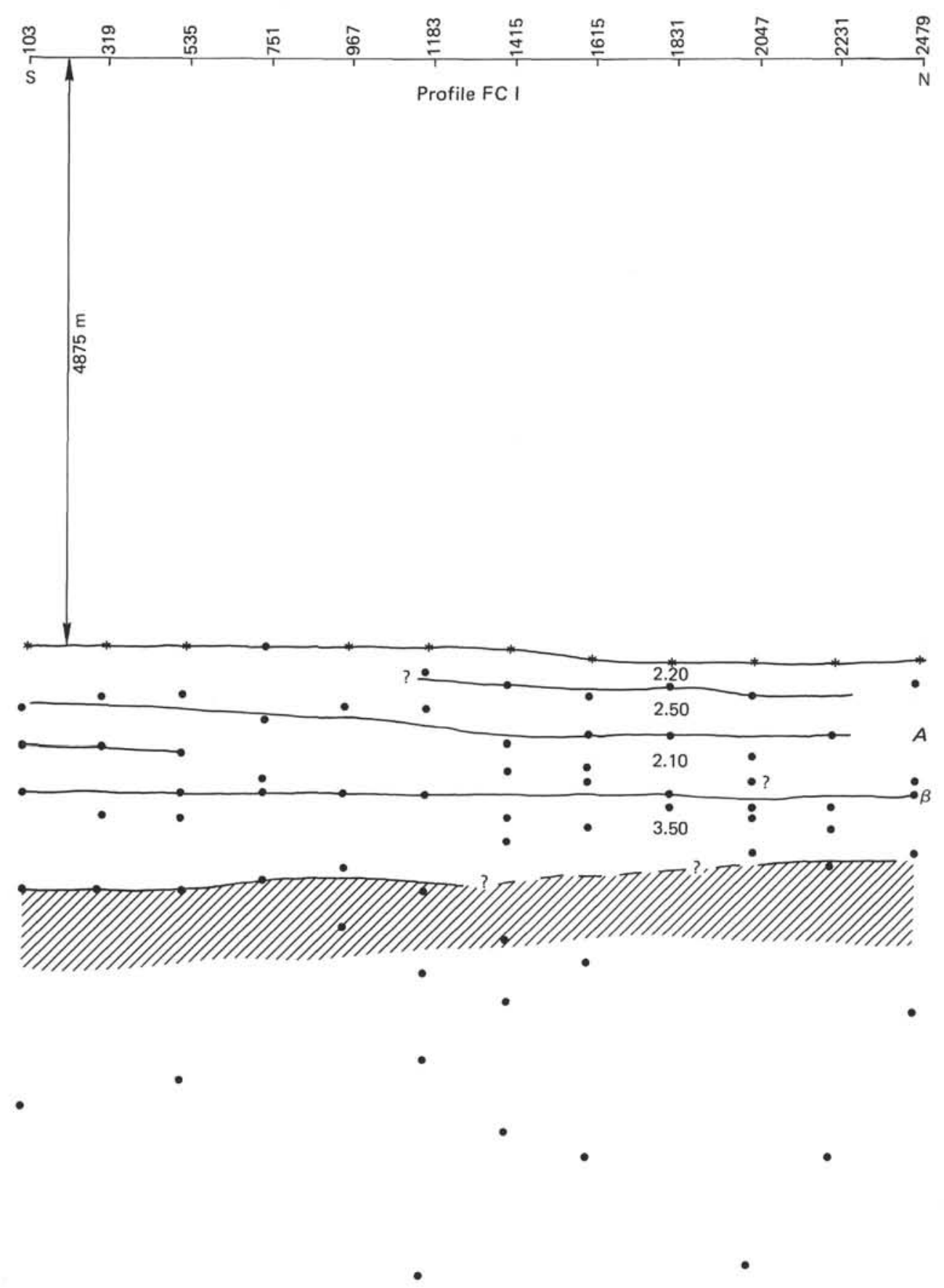

Figure 15. Location of RMS velocity picks for internal velocity calculations along profile FC II. Horizons A and $\beta$ and the interval velocities of the consistent acoustic units are also noted. 


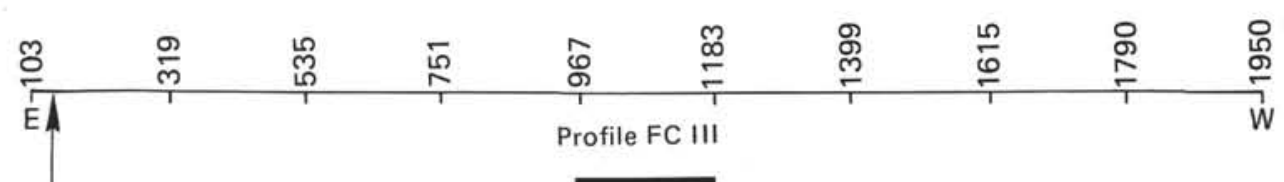

$10 \mathrm{~km}$

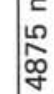

.
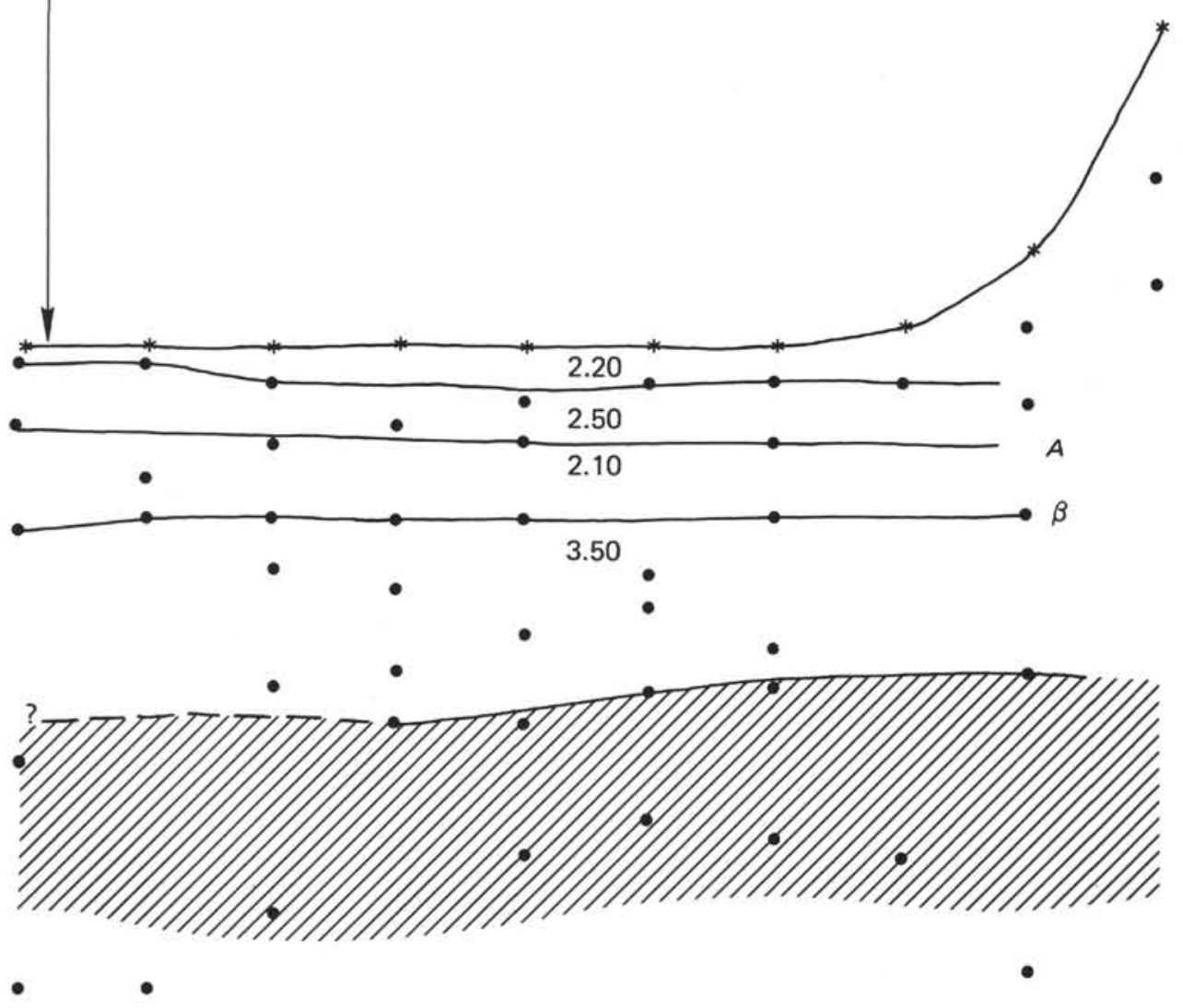

Figure 16. Location of RMS velocity picks for interval velocity calculations along profile FC III. Horizons A and $\beta$ and the interval velocities of the consistent acoustic units are also noted. 


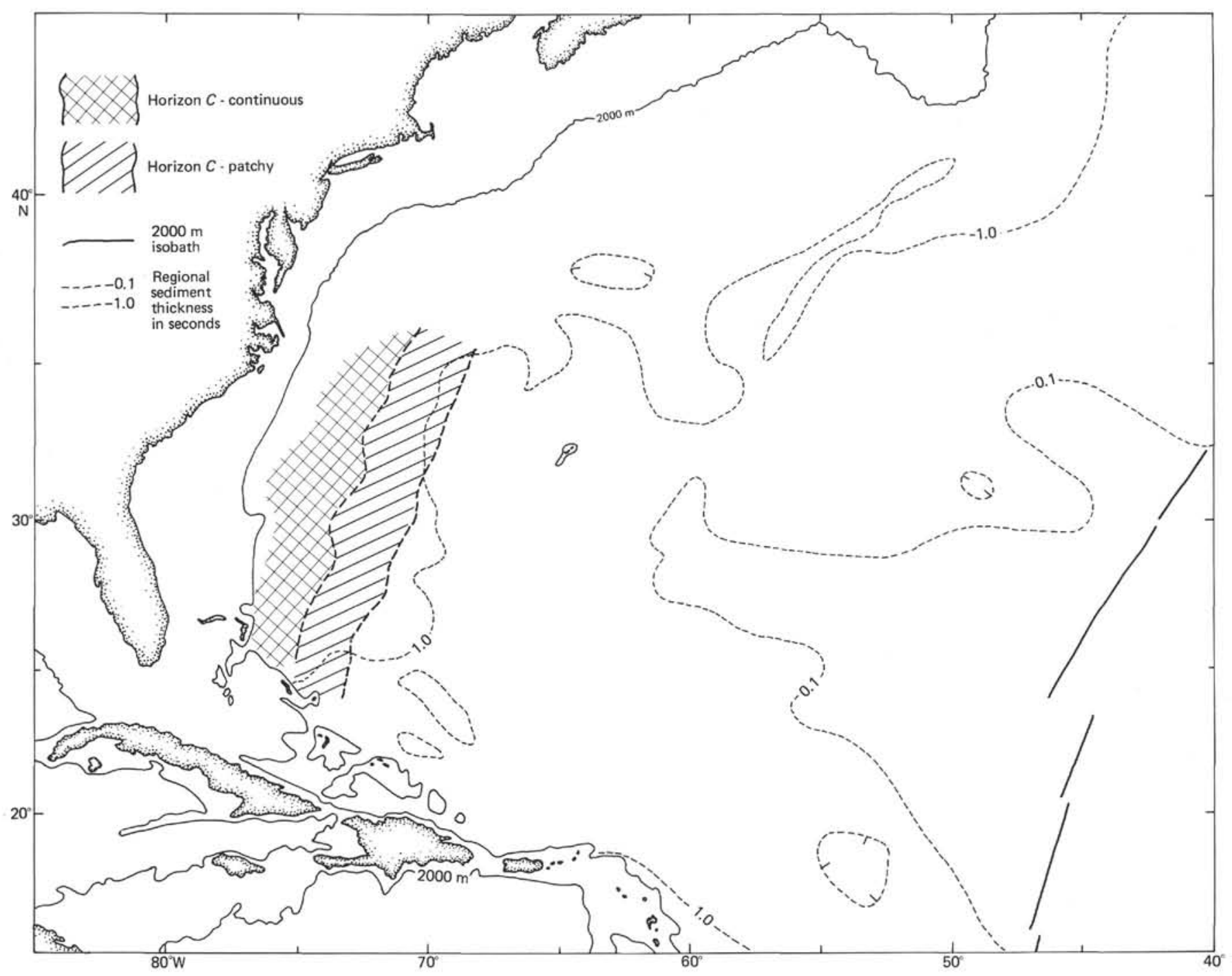

Figure 17. Map showing extent of newly defined horizon C drilled at Site 391 correlated with the interface between the Neocomian/Tithonian white limestones and the Tithonian/Kimmeridgian red argillaceous limestones. 